УДК 338:339.9.012.24

DOI: 10.35340/2308-104X.2021.91-2-08

\section{СВІТОВИЙ РИНОК ЯК СЕРЕДОВИЩЕ РОЗВИТКУ ЗОВНIШНЬОЕКОНОМІЧНОÏ СФЕРИ НАЦІОНАЛЬНОГО ГОСПОДАРСТВА}

TKAЧEHKO О.Г., кандидат економічних наук, доцент, МАЛІЧ Л. А., кандидат економічних наук, доцент, Донецький державний університет управління

\section{THE WORLD MARKET AS AN ENVIRONMENT FOR THE DEVELOPMENT OF THE FOREIGN ECONOMIC SPHERE OF THE NATIONAL ECONOMY}

\author{
TKACHENKO O. \\ $\mathrm{PhD}$ in Economics, Associate \\ Professor, \\ MALICH L., \\ $\mathrm{PhD}$ in Economics, Associate \\ Professor, Donetsk State \\ University of Management
}

В статті обґрунтовано необхідність знання сучасної ситуації, що склалася на світовому ринку, проаналізовано поточний стан $і$ визначено основні траєкторії змін, виділено періоди порушення основної тенденції зростання і надано їм характеристику. Виділено основні тенденції і особливості змін світового ринку, що мають визначальне значення для розвитку зовнішньоекономічної сфери національного господарства України.

Ключові слова: світовий ринок, світова торгівля, світовий експорт і імпорт, зовнішньоекономічна діяльність, зовнішньоекономічна сфера національного господарства.

В статье обоснована необходимость изучения современной ситуации, сложившейся на мировом рынке, проанализировано текущее состояние и определены основные траектории изменений, выделены периоды нарушения основной тенденции роста и дана им характеристика. Выделены основные тенденции и особенности изменений на мировом рынке, имеющие важное значение для развития внешнеэкономической сферы национального хозяйства Украины.

Ключевые слова: мировой рынок, мировая торговля, мировой экспорт и импорт, внешнеэкономическая деятельность, внешнеэкономическая сфера национального хозяйства.

The article substantiates the need to study the current situation in the world market, analyzes the current state and identifies the main trajectories of changes, identifies periods of violation of the main growth trend and gives them a characteristic. The main trends and features of changes in the world market are highlighted, which are important for the development of the foreign economic sphere of the national economy of Ukraine.

Key words: world market, world trade, world exports and imports, foreign economic activity, foreign economic sphere of the national economy.

Постановка проблеми. Світовий ринок, в межах якого протікає торгівельна діяльність, займає особливе місце у складній системі світового господарства. Він постає одним із джерел формування світової економічної системи, що поєднує національні господарства окремих країн і підвищує рівень їх взаємозалежності. Протягом десятиріч торгівля в межах світового ринку залишається найбільш динамічною формою міжнародних економічних відносин, що утворює середовище реалізації зовнішніх економічних інтересів кожної 
економіки світу. Інтегроване до цієї складної і масштабної економічної системи національне господарство України функціонально пов'язано із багатьма сегментами світового ринку, від стану кон'юнктури яких залежать можливості реалізації наявного потенціалу провідних галузей національної економіки. Все це підтверджує зростаючу актуальність і практичну значущість постійного вивчення стану і тенденцій розвитку світового ринку 3 метою коригування економічної поведінки і обґрунтування напрямів трансформації i розвитку як зовнішньоекономічної сфери, так і національного господарства в цілому.

Аналіз останніх досліджень. Дослідженню проблем, що пов'язані із розвитком національної економіки в контексті світових економічних процесів, в тому числі і світової торгівлі, присвячено широке коло праць вітчизняних і зарубіжних вчених. Так, в монографії Чугаєва О. А. досліджено вплив величини економіки країн на міжнародну торгівлю, визначено методи, які дозволяють оцінити економічну потужність і розподілення силового потенціалу між країнами світу і зазначено важливість факторів національного плану для розвитку міжнародних торгівельних відносин [1]. В колективному досліджені вітчизняних вчених за редакцією Осташко Т. О. наведено результати досліджень щодо впливу структурних змін у світовій торгівлі на стан, розвиток і формування політики конкурентного розвитку внутрішнього ринку України із акцентом на споживчі товари, енергоресурси, металеву продукцію і сільськогосподарський сектор, що тісно пов'язують національну економічну систему із світовим ринком [2]. Проблеми забезпечення конкурентоспроможності економіки України у глобалізованому світі досліджено у колективній монографії за редакцією Власюка О. С., в якій головна увага приділена безпековим питанням соціально-економічного розвитку країни, становленню інвестиційно-інноваційного базису цих процесів, обґрунтуванню конкурентних стратегій забезпечення економічної безпеки України в умовах глобалізації [3]. Слід зауважити, що в цих роботах наголос робиться на проблемах геоекономічного плану, а питання пов'язані безпосередньо із функціонуванням зовнішньоекономічної сфери національного господарства в межах світового ринку розглядаються опосередковано. Тому існує необхідність подальших досліджень, що пов'язані із оцінкою основних змін в структурі і динаміці розвитку світового ринку, в межах якого формується і реалізується наявний потенціал зовнішньоекономічної сфери національного господарства і економічні інтереси вітчизняних суб'єктів господарської діяльності.

Мета статті полягає у аналізі і виділені сучасних тенденцій і особливостей розвитку світового ринку і світової торгівлі, які виступають основою і інформаційною базою задля формування напрямів розвитку зовнішньоекономічної сфери національного господарства.

Виклад основного матеріалу. За своїми масштабами, функціями, динамікою розвитку світовий ринок і торгівельна діяльність на ньому $€$ середовищем і провідним видом економічних відносин, що охоплює практично всі країни світу. Саме в цьому середовищі національна економіка кожної країни реалізує свої зовнішньоекономічні інтереси, що пов'язані, в першу чергу, із продажем і купівлею певних товарів і послуг, формує імідж країни, як учасника певних сегментів світового ринку, вирішує питання розвитку і економічної безпеки, формуючи 
стратегії і програми структурних змін у відповідності до вимог ринку із врахуванням власних інтересів $[4,5]$.

Характеристика світового ринку, його стану і тенденцій розвитку пов'язана із аналізом динаміки і структури світової торгівлі і визначенням особливостей його певних сегментів.

Аналіз динаміки світового експорту, який охопив період із 2001 по 2020 рр. показав доволі стійку тенденцію зростання. За цей період загальний обсяг світової торгівлі збільшився майже в тричі (рис. 1) і у 2020 р. перевищив 22,5 трлн дол. США. На торгівлю товарами у 2020 р. приходилося $78 \%$, а на торгівлю послугами - 22\%. Протягом усього періоду із певними коливаннями спостерігалося поступове збільшення частки послуг, на які у 2001 р. приходилося 19,2\%.

30000

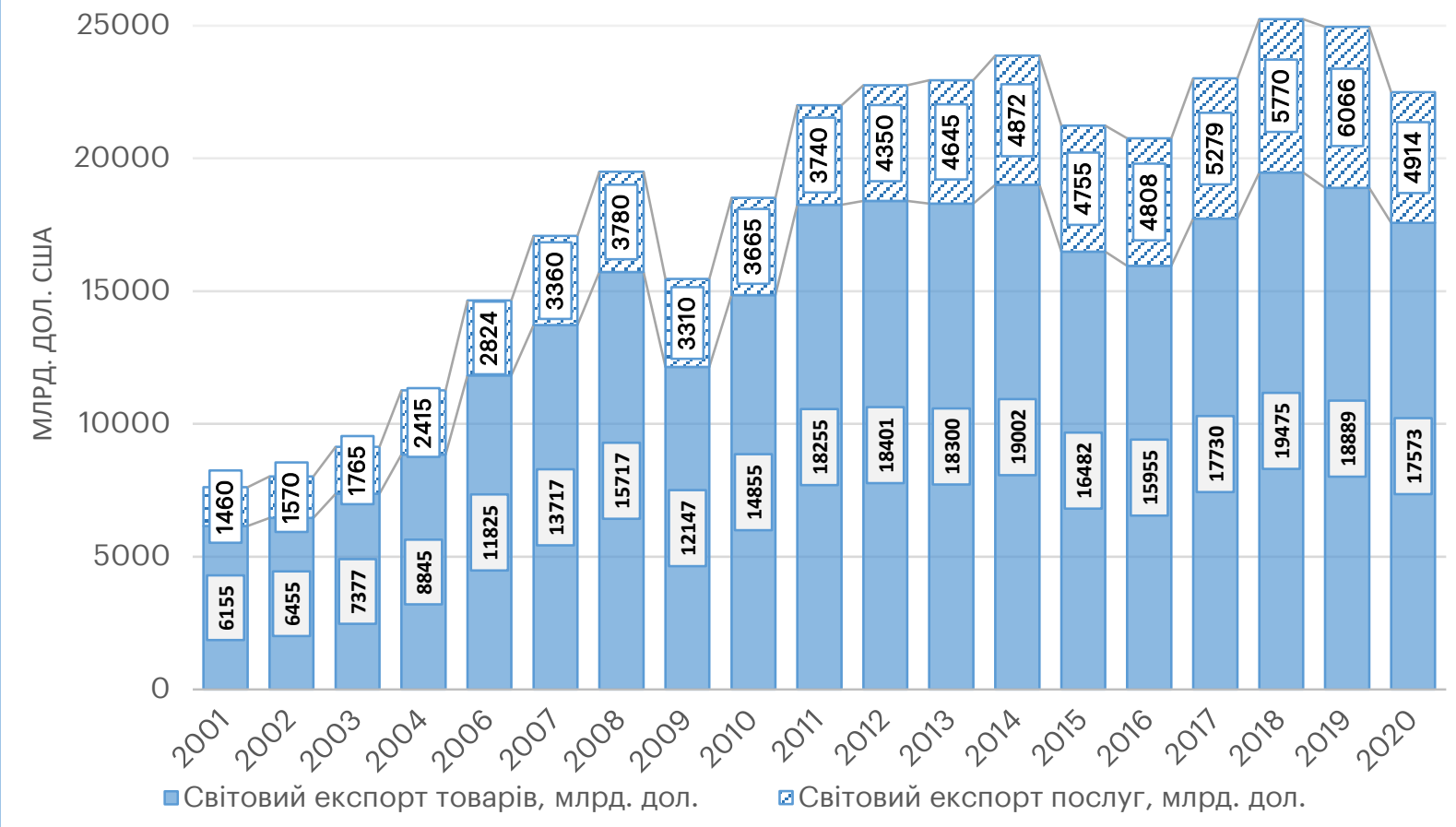

Рис. 1. Світова торгівля товарами і послугами, 2001-2020 рр. Побудовано автором на підставі даних [6]

Загальна тенденція зростання світової торгівлі за цей період була порушена тричі:

у 2009 р., коли обсяги світової торгівлі зменшився більш ніж на $20 \%$, в тому числі по товарах - на 22,7\%, по послугах - на $12,4 \%$;

у 2015-2016 рр., коли скорочення перевищило 13\% за два роки;

у 2019-2020 рр., коли обсяги торгівлі за два роки зменшилися на $11 \%$, із яких на 2020 р. приходилося $9 \%$.

Причини зниження вартісного обсягу світового експорту за названими періодами різняться. Так у 2008-2009 рр. основною причиною був негативний вплив на ринок світової фінансової кризи, яка призвела до скорочення не лише торгівлі, а й світового виробництва. Значні падіння обсягів торгівлі і виробництва були характерні для такого важливого для України сегменту ринку як ринок металургійної продукції. Фінансова криза спровокувала актуалізацію 
спадної фази чергового циклу розвитку даної галузі, а низхідна динаміка спостерігалася вперше з 1998 р., коли ринок металопродукції зазнав впливу негативних наслідків азійської фінансової кризи [7, с. 45]. Масштабність кризових явищ була значною і призвела до значного зниження виробництва майже у всіх провідних експортерів металургійної продукції.

Протягом 2015-2016 рр. поточна доларова вартість світового експорту товарів і послуг знизилася на $11 \%$ у 2015 р. і на 2,2\% - у 2016 р. Таке скорочення в більшому ступені мало відношення до товарного експорту, який у 2015 р. знизився на 13\% до 16,5 трильйонів доларів США. Слід зазначити, що фізичний обсяг торгівлі товарами у 2015 р. лише уповільнився до 2,4\%, а різке скорочення його доларової вартості мало місце в результаті зниженням на 15\% експортних цін. Основними причинами такої ситуації на світовому ринку стали такі фактори як уповільнення економіки Китаю, рецесія в економіці Бразилії, падіння цін на нафту та інші сировинні товари, нестабільність курсу валют. Саме в країнах Азії та економіках, що базуються на ресурсах значно знизився попит на імпорт [8]. При певному покращенні тенденція зниження доларової вартості і уповільнення світової торгівлі товарами до 1,3\% продовжилося у 2016 р. Частково це було викликано ослаблення інвестиційних витрат, які $€$ найбільш інтенсивною складовою для торгівлі і попиту на імпорт. Торгівля комерційними послугами у вартісному виражені у 2016 р. зафіксувала незначне зростання і піднялася до 4,8 трлн дол. США. Найслабшим компонентом послуг був транспорт, який, як правило, відображає коливання у торгівлі товарами [9].

Зниження обсягів світової торгівлі у 2019-2020 рр. пов'язано із впливом пандемії COVID-19, яка стала причиною значного економічного спаду, зниження обсягів світової торгівлі і певних змін на світовому ринку. За два роки вартісний обсяг світової торгівлі зменшився на 11\% після значного зростання у 2018 р. (+ 9,7\% за рік). Скорочення обсягів торгівлі було більш повільним у 2019 р. (- 1,1\%) і значно інтенсивнішим у 2020 р. (- 9,8\%).

Ще протягом 2019 р. усі регіони світу зафіксували зниження товарообігу за обсягом та вартістю. Найбільшим падіння було у Південній та Центральній Америці та Карибському басейні. Вартість світової торгівлі товарами знизилася майже на 3,0\% за рахунок країн Європі та Азії, на які припадає майже дві третини світового товарного ринку. Зміни на ринку різнилися виходячи із виду товару і регіону. Так, експорт промислових товарів скоротився на 2,0\%, палива та гірничодобувної промисловості - на 7,5\%, що було викликано значним падінням цін на енергоносії (-17\%). При цьому експорт сільськогосподарської продукції скоротився лише на 1,5\%, що $є$ меншим відносно загального скорочення світового експорту в цілому. Відносно експорту послуг слід зазначити лише уповільнення темпів зростання до 2,1\% у 2019 р. За структурою послуг зміни були нерівнозначними. Так, експорт транспортних послуг скоротився майже на 1\% на фоні економічної невизначеності та торгівельної напруги, а комп'ютерні послуги зросли на 11\%, продовжуючи зростання після фінансової кризи 2009 р. В інших секторах ринку послуг спостерігалося сповільнення зростання у порівнянні із 2018 р. у всіх основних секторах [10].

Ще у більшому ступені пандемія COVID-19 вплинула на результати торгівлі у 2020 р. За думкою фахівців, спад у світові 
економіці в наслідок пандемії COVID-19 став найсильнішим із 1930-х років [11, с. 7]. Вартісний обсяг світової торгівлі скоротився майже на 10\%, товарний експорт - майже на 7\%, експорт послуг - майже на 19\%. Зміни були різними у різних секторах ринку. Серед ринкових сегментів найбільший негативний вплив відчув на собі ринок автомобілів, світовий експорт на якому скоротився на 16\%. Іншою була ситуація на ринку текстильних виробів і медичних товарів, де експорт збільшився в обох секторах на $16 \%$ у результаті зростання виробництва засобів індивідуального захисту, ліків, медичного обладнання та засоби індивідуального захисту. Таким чином, відреагувала світова торгівля на зростання попиту і надала можливість багатьом країнам мати доступ у до критично важливих товарів в умовах пандемії.

Аналіз змін на світовому ринку в умовах впливу пандемії показав, що більш стійкими в ланцюгах доданої вартості $€$ сегменти високотехнологічних товарів та фармацевтичних і медичних виробів. Попит на комп'ютерні послуги значно збільшився на фоні переходу до дистанційних форм роботи і призвів до зростання цифрових платформ, які надають такі можливості.

Найбільш уразливим сегментом став туристичний сектор на фоні закриття кордонів, карантинних вимог та інших обмежень. Так, глобальний експорт подорожей скоротиться на 62\% у 2020 р., оскільки більшість країн світу ще не були щеплені і з'явилися нові варіанти коронавірусу, який і досі залишається однією із головних загроз для відновлення економіки та торгівлі.

Світовий ринок і світова торгівля, і їх значення для світового господарства продовжують зростати, про що свідчать зміни співвідношення між обсягами світового експорту товарів і послуг і світового ВВП. Так, у 2001 р. це співвідношення ледве перевищувало 25\%, до 2008 р. воно збільшилося до 30\%, розгортання світової фінансової кризи 2008-2009 рр. зменшило його величину до 26,5\%, яка вже у 2011 р. знову перевищила 30\%. Незначною мірою означене співвідношення знизилося у 2015-2016 рр. і у 2019-2020 рр. Враховуючи значний кризовий стан саме 2019-2020 рр. зниження величини цього показника було значно повільнішим, ніж загальний спад у світовій торгівлі, що лише підтверджує тезу зростання значення світової торгівлі і світового ринку як середовища розвитку не лише зовнішньоекономічної сфери національного господарства країни, а й національної економіки в цілому. Світова торгівля та ВВП тісно пов'язані між собою, демонструють однакові тенденції зростання, але торгівля більш схильна до коливання, особливо в періоди падіння (рис. 2). Аналіз цього співвідношення показав, що протягом 2001-2007 рр. експорт зростав значно більш високими темпами ніж ВВП, але і падіння його обсягів у 2008-2009 рр. теж було значнішим і становило більш ніж 20\%, на відміну від зниження ВВП, яке оцінювалося на рівні $8 \%$.

Повільна посткризова економічна експансія супроводжувалася усередненими, але дещо більшими темпами у торгівлі. Тенденція зростання розбіжності повторилася у 2020 р. під впливом пандемії, коли темпи падіння світового ВВП були вдвічі менші, ніж світового експорту. Порівняння темпів зниження реального ВВП і обсягу світової торгівлі товарами показали, що в першій половині 2020 р. внаслідок пандемії COVID-19 вони значно знизилися, але потім відновилися у другій половині. В результаті обсяг торгівлі товарами у 2020 р. 
зменшився на 5,3\%, тоді як реальний ВВП за ринковими курсами зменшився на 3,6\%.

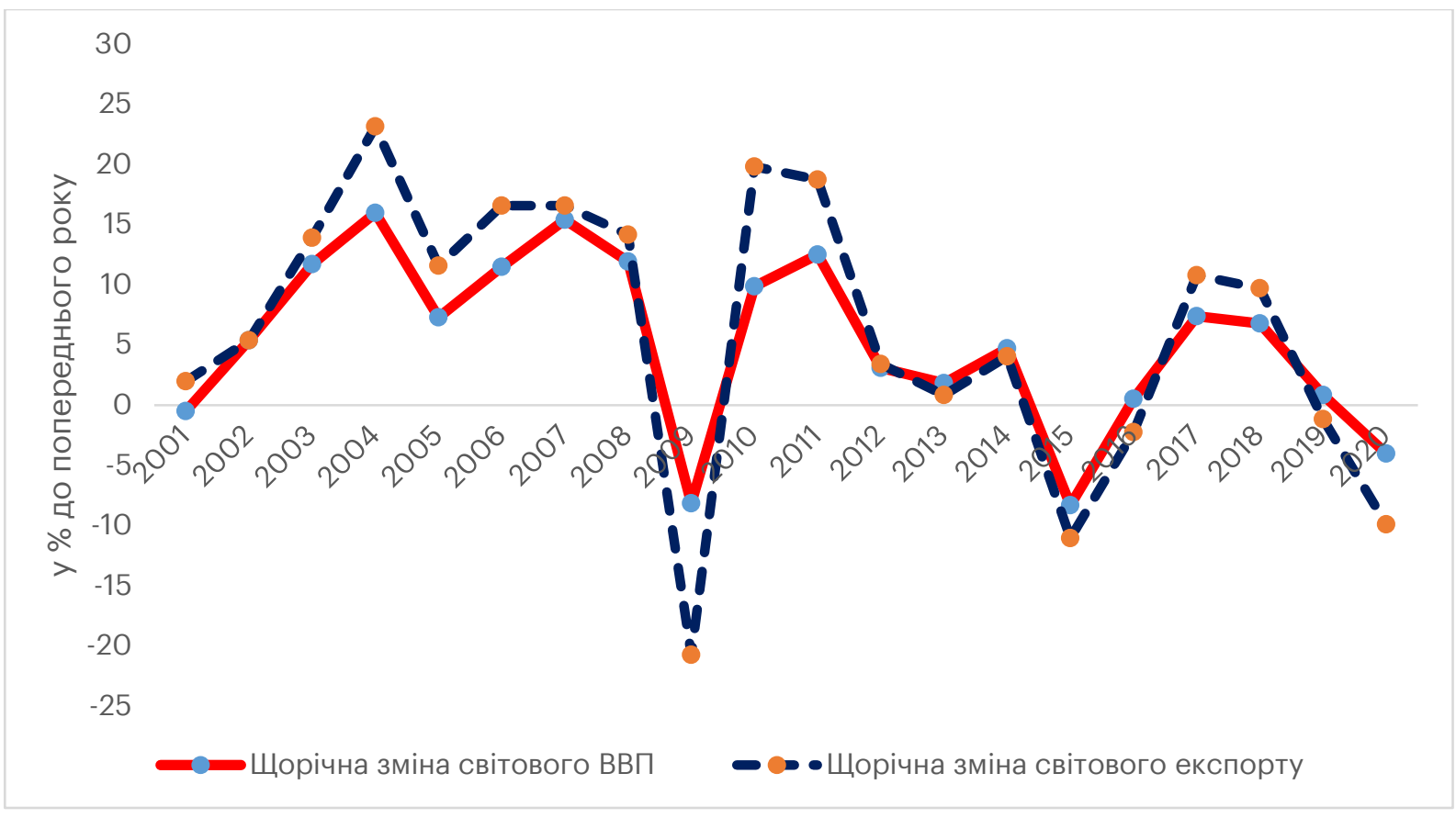

Побудовано автором на підставі [12]

Рис. 2. Зміна обсягів світового ВВП і світового експорту, 2001-2020 pp.

Торгівля товарами та комерційними послугами в поточних цінах значно знизилися на ранніх стадіях пандемії. У другій половині 2020 р. торгівля товарами різко збільшилася на відміну від сектору послуг, в якому продовжилася низхідна траєкторія. В результаті вартість товарного експорту зменшилася на 8\% до 17,58 трлн дол. США, тоді як експорт комерційних послуг скоротився на 20\% до 4,91 трлн доларів США [11].

Висновки і перспективи подальших досліджень. Проведений аналіз показав, що протягом 2001-2020 рр. світовий ринок змінювався під впливом багатьох факторів, які визначили його сучасну конфігурацію. Сучасний стан світового ринку як середовища розвитку зовнішньоекономічної сфери національного господарства характеризується наступними тенденціями і особливостями:

значним зростанням обсягів світової торгівлі протягом останніх двох десятиліть, підвищенням ролі світового ринку для процесів економічного зростання країн, різким зниженням обсягів у кризові періоди і більш значними темпами зростання відносно змін світового ВВП і світового виробництва, значним зростанням цін, особливо в таких сегментах ринку як енергоносії, метали і продовольство, що відображає особливості формування ланцюгів міжнародних постачань i знаходить відображення у зростанні глобальності виробничих мереж або ланцюжків створення вартості;

значною часткою товарного експорту на внутрішньо регіональних ринках країн Європи, Азії і Північної Америки. Так, у Європі торгівля в межах регіону оцінюється у розмірі $70 \%$ від загального товарного експорту регіону, в Азії більше половини всього 
її експорту продається в межах країн цього регіону, в Північній Америці іï обсяги дорівнюють майже 50\%;

зміною співвідношення в структурі торгівлі товарами між розвиненими країнами і країнами, що розвиваються, в сторону збільшення частки останніх і зменшенням частки країн розвинених. При цьому певну незначну позицію займають країни СНД, в т.ч. асоційовані і колишні. Їх частка протягом цього періоду зросла із 2,3\% у 2001 р., до 3,7\% - у 2010 р. і знизилася до 3,1\% у 2020 р. Частка країн, що розвиваються, протягом цього періоду досить інтенсивна зростала до 2010 р. (із 31,1\% у 2001 р. до 42,1\% у 2010 р.), а потім зростання уповільнилося. Слід зазначити, що в цілому таке зростання було пов'язано зі зміною місця Китаю в структурі світового експорту. Із врахуванням цього факту частка країн, що розвиваються, за останні 10 років збільшилася несуттєво [13];

продовженням зростанням значення Китаю в структурі світового ринку, який нині $€$ провідним світовим експортером. Китай, який вступив до СОТ у 2001 р. досить швидко опанував перші позиції в світі, у 2004 р. він обігнав Японію - провідного азіатського експортера, у 2007 р. - США і у 2009 р. - Німеччину. Першу позицію він утримує до теперішнього часу (із часткою у 14,7\% за даними 2020 р.);

майже незмінною протягом останніх 10 років частки $Є С$ в обсягах світового експорту, яка $€$ найбільшою серед регіональних об'єднань і знаходиться на рівні 15-15,4\% (за виключенням торгівлі всередині ЄС), a із врахуванням торгівлі між країнами ЄС ця часка перевищує $30 \%$ світового експорту. Крім того, ЄС входить до трійки найкрупніших імпортерів товарів, займає провідні позиції на ринку комерційних послуг, експортуючи за межі ЄС і імпортуючи майже 25\% від світової торгівлі комерційними послугами;

незначними змінами на ринку сільськогосподарської продукції, де протягом 2001-2020 рр. провідними світовими експортерами залишаються ЄС, США, Бразилія, Китай, Канада, Індонезія, Таїланд, Мексика, Індія, Аргентина, сумарна частка яких у 2020 р. дещо перевищувала 70\% світового експорту, що лише на 2 відсоткові пункти менше, ніж у 2001 р., а основними імпортерами - ЄС, Китай, США, Японія, Велика Британія, Канада, Південна Корея, РФ, Мексика і Індія (разом 71\% загального імпорту 2020 р.), частка яких за цей період зменшилася лише на 5 відсоткових пункти за рахунок зменшення імпорту до ЄС, США і Японії при значному (в 3,5 рази) зростанні імпорту до Китаю [11];

більш значними змінами на ринку палива та гірничодобувної продукції, де частка найкрупніших експортерів (ЄС, США, РФ, ОАЕ, Саудівська Аравія, Австралія, Канада, Китай, Бразилія, Велика Британія) за 2001-2020 рр. збільшилася майже на 10 відсоткових пунктів (в основному за рахунок збільшення експорту з США, ОАЕ і Австралії) при незначному знижені загальної частки найкрупніших імпортерів, яка у 2020 р. становила 77\%, що на 1,5 відсоткових пункти менше ніж у 2001 р., але у структурі головних імпортерів відбулися значні зміни. Так, частки ЄС, США і Японії значно скоротилися, а Китаю і Індії значно зросли [11];

змінами на світовому ринку послуг, що пов'язані і зі зростанням його загального обсягу і незначною зміною в сторону збільшення частки у світовій торгівлі. Світова торгівля комерційними послугами за останне десятиліття щорічно зростала в середньому на 2\%, а такі категорії послуг, як комп'ютерні, інформаційні, фінансові, часто 
випереджали середній підйом. Інформаційні технології були найстійкішим сектором послуг і під час світової фінансової кризи, і в умовах впливу пандемії COVID-19 через постійний попит на економічно ефективні технології, розвиток інноваційного програмного забезпечення, зростаючу потребу розширення спектру послуг, що надаються у цифровому вигляді і вирішення проблем безпеки IT. Крім того, нові технології, покращений доступ до Інтернету та електронні системи оплати та доставки створили новий засіб торгівлі електронну комерцію, що допомогло скоротити торгові витрати, а також вирішувати проблеми торгівлі в умовах пандемії COVID-19.

Дослідження поточної ситуації на світовому ринку, знання ії особливостей і тенденцій розвитку виступає певними орієнтирами для розвитку зовнішньоекономічної сфери національного господарства України, дозволяє оцінити можливі наслідки для національної економіки і визначити перспективні сектори для розвитку. Подальші дослідження доцільно зосередити на питаннях ініціації системноструктурних зрушень цієї сфери національного господарства, що має стати потужним рушієм зростання для економіки країни в цілому.

\section{Література:}

1. Чугаєв О.А. Глобальні виміри економічної сили країни: монографія. Київ: Київський університет, 2017. 495 с.

2. Структурні зміни у світовій торгівлі як чинник розвитку внутрішнього ринку України: колективна монографія / за ред. Т. О. Осташко; НАН України, ДУ «Ін-т екон. та прогнозув. НАН України». Київ, 2019. 350 с. URL: http://ief.org.ua/docs/mg/310.pdf.

3. Безпека та конкурентоспроможність економіки України в умовах глобалізації: монографія / за заг. ред. О. С. Власюка. Київ: НІСД, 2017. 384 c.

4. Механізми розвитку і безпеки економіки та суспільства: монографія / заг. ред. проф. В. В. Дятлової. Маріуполь: ДонДуУ, 2015. 246 c.

5. Дятлова В. В. Забезпечення економічної безпеки i конкурентоспроможності економіки механізмами технічного регулювання. Актуальні проблеми економіки. 2011. № 3 (117). С. 56-62.

6. World Trade Report. URL: https://www.wto.org/english/res_e/ reser_e/wtr_e.htm.

7. Батченко Л.В., Ащурков О.О., Ткаченко О.Г. Методика системної діагностики впливу стану зовнішньої торгівлі на зміну рівня економічного суверенітету України. НАН України, Ін-т економікоправових досліджень. Донецьк: Юго-Восток, 2012. 77 с.

8. World Trade Statistical Review 2016. World Trade Organization. 2016. 163 p. URL:https://www.wto.org/english/res_e/statis_e/wts2016_e/ wts16_toc_e.htm.

9. World Trade Statistical Review 2017. World Trade Organization. 2017. 177 p. URL:https://www.wto.org/english/res_e/statis_e/wts2017_e/ wts17_toc_e.htm.

10. World Trade Statistical Review 2020. World Trade Organization. 2020. 154 p. URL:https://www.wto.org/english/res_e/statis_e/wts2020_e /wts2020_e.pdf.

11. World Trade Statistical Review 2021. World Trade Organization. 2021. 134 p. URL:https://www.wto.org/english/res_e/statis_e/wts2021_e/ wts21_toc_e.htm. 
12. UNCTADSTAT. URL:https://unctadstat.unctad.org/wds/TableVie wer/tableView.aspx.

\section{References:}

1. Chughajev O.A. Ghlobaljni vymiry ekonomichnoji syly krajiny: monoghrafija. Kyjiv: Kyjivsjkyj universytet, 2017. 495 s.

2. Strukturni zminy u svitovij torghivli jak chynnyk rozvytku vnutrishnjogho rynku Ukrajiny: kolektyvna monoghrafija / za red. T. O. Ostashko; NAN Ukrajiny, DU «In-t ekon. ta proghnozuv. NAN Ukrajiny». Kyjiv, 2019. 350 s. URL: http://ief.org.ua/docs/mg/310.pdf.

3. Bezpeka ta konkurentospromozhnistj ekonomiky Ukrajiny $v$ umovakh ghlobalizaciji: monoghrafija / za zagh. red. O. S. Vlasjuka. Kyjiv: NISD, 2017. $384 \mathrm{~s}$.

4. Mekhanizmy rozvytku i bezpeky ekonomiky ta suspiljstva: monoghrafija / zagh. red. prof. V. V. Djatlovoji. Mariupolj: DonDUU, 2015. $246 \mathrm{~s}$.

5. Djatlova V.V. Zabezpechennja ekonomichnoji bezpeky i konkurentospromozhnosti ekonomiky mekhanizmamy tekhnichnogho reghuljuvannja. Aktualjni problemy ekonomiky. 2011. \# 3 (117). S. 56-62.

6. World Trade Report. URL:https://www.wto.org/english/res_e/ reser_e/wtr_e.htm.

7. Batchenko L. V., Ashhurkov O. O., Tkachenko O. Gh. Metodyka systemnoji diaghnostyky vplyvu stanu zovnishnjoji torghivli na zminu rivnja ekonomichnogho suverenitetu Ukrajiny. NAN Ukrajiny, In-t ekonomiko-pravovykh doslidzhenj. Donecjk: Jugho-Vostok, 2012. 77 s.World Trade Statistical Review 2016 / World Trade Organization. 2016. 163 p. URL:https://www.wto.org/english/res_e/statis_e/wts2016_e/wts16 toc e.htm.

8. World Trade Statistical Review 2016. World Trade Organization. 2016. 163 p. URL:https://www.wto.org/english/res_e/statis _e/wts2016_e/wts16_toc_e.htm.

9. World Trade Statistical Review 2017. World Trade Organization. 2017. 177 p. URL:https://www.wto.org/english/res_e/statis_e/wts2017_e/ wts17_toc_e.htm.

10. World Trade Statistical Review 2020. World Trade Organization. 2020. 154 p. URL:https://www.wto.org/english/res_e/statis_e/wts2020_e /wts2020_e.pdf.

11. World Trade Statistical Review 2021. World Trade Organization. 2021. 134 p. URL:https://www.wto.org/english/res_e/statis_e/wts2021_e/ wts21_toc_e.htm.

12. ŪNCTADSTAT. URL: https://unctadstat.unctad.org/wds/TableVi ewer /tableView.aspx.

The main purpose of this work is analysis and selection of current trends and features of the world market and world trade, which serve as the basis and information base for the formation of directions of development of the foreign economic sphere of the national economy.

The analysis, which covered the period from 2001 to 2020, revealed the main growth trend, which was broken three times during this period: in 2009; in 2015-2016; in 2019-2020. The reasons for the decline in the value of world exports during these periods were different. 
In 2008-2009, the main reason was the negative impact of the global financial crisis on the market. In 2015-2016, the main reasons were cyclical factors: the slowdown in China's economy, the recession in the Brazilian economy, falling prices for oil and other commodities, exchange rate instability. In 2019-2020, the COVID-19 pandemic caused a significant economic downturn, declining world trade and some changes in the world market.

During 2001-2020, the world market changed under the influence of many factors that determined its current configuration. The analysis allowed to identify the following trends and features:

significant growth in world trade over the past two decades, increasing the role of the world market for economic growth, increasing the globalization of production networks or value chains;

significant share of merchandise exports in the domestic markets of Europe, Asia and North America;

changing the ratio in the structure of trade in goods between developed and developing countries in the direction of increasing the share of the latter and decreasing the share of developed countries;

continued growth of China's importance in the structure of the world market;

almost unchanged over the last 10 years, the EU's share of world exports, which is the largest among regional associations;

minor changes in the agricultural market, where the configuration among the leading exporting and importing countries has hardly changed, with the exception of declining imports to the EU, the US and Japan with significant growth in China;

more significant changes in the fuel and mining market, where the share of the largest exporters increased by almost 10 percentage points, while the shares of the EU, US and Japan decreased significantly, and China and India - increased significantly;

changes in the world market of commercial services, which are associated with a gradual increase in its total volume, share in world trade and changes in the structure of services. The most resilient service sector, both during the global economic crisis and in the context of the COVID-19 pandemic, was information technology and services provided in digital form. 